\title{
Body fish size tendencies within and among species in the deep-sea of the western Mediterranean*
}

\author{
JOAN MORANTA ${ }^{1}$, MIQUEL PALMER ${ }^{1}$, \\ ENRIC MASSUTÍ2, CONSTANTÍ STEFANESCU ${ }^{3}$ \\ and BEATRIZ MORALES-NIN ${ }^{1}$ \\ ${ }^{1}$ Institut Mediterrani d'Estudis Avançats (UIB-CSIC), Miquel Marquès 21, 07190 Esporles, Spain. \\ E-mail: joan.moranta@uib.es \\ ${ }^{2}$ IEO - Centre Oceanogràfic de les Balears, P.O. Box 291, 07080 Palma de Mallorca, Spain. \\ ${ }^{3}$ Museu de Granollers - Ciències Naturals, Francesc Macià 51, E-08400 Granollers, Spain.
}

SUMMARY: Data collected south-west of the Balearic Islands (Western Mediterranean) on two cruises, Quimera-I (October, 1996) and Quimera-II (May, 1998), were used to establish general ecological patterns in deep-sea fish assemblages. A total of 39 trawls were taken at depths between 400 and $1714 \mathrm{~m}$. Fish assemblages were analysed in terms of species composition, ecological parameters and biomass spectra. Differences in species composition between cruises and depth (Upper slope: 400-800 m, Middle slope: 801-1400 m and Lower slope: 1401-1714 m depth) were evaluated using multivariariate analysis. The most important feature was the existence of a biomass peak at intermediate depths. Moreover, the analysis of the biomass spectra indicated the absence of large individuals at the shallower depth interval considered. To determine the causes of the biomass peak on the middle slope four hypothesis were explored: (1) species richness is higher on the middle slope; (2) the fish assemblage from the middle slope can be characterised by the highest abundance (number of fish/area); (3) species found on the middle slope are larger (the species assemblage is built up by larger species); and (4) there is a trend for the specimens of several species to be larger at the middle slope. The data gathered support that the biomass peak is better explained by the existence of abundance peaks of medium and large-sized species, and by the presence of some of the largest individuals of other large-sized species, in both cases related to specific depth size trends which do not always follow a bigger-deeper trend.

Key words: demersal, deep-sea, community, biomass, body mass, ecological parameters, western Mediterranean.

RESUMEN: TENDENCIAS INTER E INTRA-ESPECÍFICAS EN EL TAMAÑO DE LOS PECES DE GRAN PROFUNDIDAD DEL MEDITERRÁNEO OCCIDENTAL. - Los datos analizados se han recogido al sureste de las Islas Baleares en dos campañas Quimera-I (Octubre, 1996) y Quimera-II (Mayo, 1996). Se realizaron un total de 39 pescas de arrastre entre 400 y $1714 \mathrm{~m}$ de profundidad. Se analizó la composición específica, parámetros ecológicos y espectros de biomasa de la comunidad íctica de profundidad. La característica más importante fue la existencia de un pico de biomasa a profundidades intermedias. El análisis de los espectros de biomasa indicó que no aparecían individuos de gran tamaño a menor profundidad. Las causas que pueden determinan la aparición de este pico de biomasa en el talud medio, se han examinado a partir de cuatro alternativas: (1) mayor riqueza específica a profundidades intermedias, (2) mayor abundancia de algunas especies en este intervalo de profundidad; (3) mayor tamaño de las especies, (4) tendencia de los ejemplares de algunas especies a ser más grandes a profundidades intermedias. La principal causa que puede explicar este pico de biomasa está relacionada con las respuestas individuales y específicas al gradiente batimétrico, ya que la abundancia de ciertas especies de tamaño medio y grande presenta un pico en esta profundidad, y además individuos de gran talla de otras especies de gran tamaño también son más abundantes. Ambas posibilidades no siempre se relacionan con una tendencia al aumento de la talla con la profundidad.

Palabras clave: ictiofauna demersal, mar profundo, comunidad, parámetros ecológicos, espectros de biomasa, masa corporal, Mediterráneo occidental.

*Received February 15, 2003. Accepted April 27, 2004. 


\section{INTRODUCTION}

Depth-related zonation of dominant megafaunal groups has been described for many deep-sea areas (Haedrich et al., 1980; Merrett and Marshall, 1981; Koslow, 1993), including the Mediterranean Sea (Cartes and Sardà, 1993; Stefanescu et al., 1993; Moranta et al., 1998). The depth gradient has been repeatedly reported as the main factor affecting species distribution in demersal fish communities (e.g. Haedrich and Krefft, 1978; Snelgrove and Haedrich, 1985; Koslow, 1993; Gordon et al., 1995). The species-specific depth distributions show highly distinctive patterns, varying from species found over a wide range to those restricted to a narrow band. Although closely related megafaunal species overlap considerably along the bathymetric gradient, each species appears to show different depth optima (Hecker, 1990).

Concerning fishes, general depth-related patterns for the species richness, abundance and biomass have been reported. Species richness decreases progressively from the upper slope down to about 2000 m depth (Haedrich et al., 1980; Pearcy et al., 1982; Gordon and Duncan, 1985). In the case of abundance, an exponential decrease with depth has been described by several authors (Grassle et al., 1975; Cohen and Pawson, 1977; Merrett and Domanski, 1985; Gordon, 1986; Merrett et al., 1991), although a stable tendency below a depth of $500 \mathrm{~m}$ seems to occur in the Mediterranean (Stefanescu et al., 1993; Moranta et al., 1998). The most important feature for fish biomass is the existence of a peak at intermediate depths of 800 and $1500 \mathrm{~m}$ depending on the areas surveyed (Marshall and Merrett, 1977; Gordon and Duncan, 1985; Gordon, 1986). In the western Mediterranean this biomass peak has been found between 800 and $1400 \mathrm{~m}$ depth (Stefanescu et al., 1993, 1994; Moranta et al., 1998).

The analysis of biological systems from the standpoint of size distributions and biomass spectra is obviously of great ecological relevance (Macpherson and Gordoa, 1996; and references cited therein). Body mass is a fundamental attribute of any animal and has an additional interest because most biological processes are scaled to the size of the organism (Peters, 1983). The analysis of size distributions in deep-sea fish studies focuses mainly on size depth relationships both for individual species and for the whole fauna (Haedrich and Rowe, 1977; Polloni et al., 1979; Merrett and Marshall, 1981; Sulak, 1982; Pearcy et al., 1982;
Carney et al., 1983; Mauchline and Gordon, 1984; Middleton and Musick, 1986; Gordon and Duncan, 1987; Macpherson and Duarte, 1991; Merrett et al., 1991; Stefanescu et al., 1992). The causes pointed out by these authors to explain changes of size with depth are related mainly to food availability, interor intra-specific competition and predation.

During the last two decades, some evidence has shown that biomass spectra are good descriptors of the fish assemblage structure (Haedrich and Merrett, 1992; Macpherson and Gordoa, 1996). Moreover, biomass spectra are a useful tool for examining dynamics processes at the community level and have been used in predicting the changes of deepwater fish assemblages following increasing fishing pressures (Merrett and Haedrich, 1997).

This paper has two main objectives: i) to analyse the bathymetric variations in community traits and body size spectra related to within-fauna patterns; and ii) to determine the causes of the previously described biomass peak on the middle slope (800$1400 \mathrm{~m}$ ). With respect to this last objective, four possible alternatives were explored: (1) species richness is higher on the middle slope; (2) the fish assemblage from the middle slope is characterised by the highest abundance (number of fish/area); (3) species found on the middle slope are larger (the species assemblage is built up by larger species); and (4) there is a trend for the specimens of several species to be larger on the middle slope.

\section{MATERIAL AND METHODS}

\section{Sampling procedures}

The data examined in the present paper were collected south-west of the Balearic Islands (Western Mediterranean), between $38^{\circ} 05^{\circ} \mathrm{N}$ and $38^{\circ} 48^{\circ} \mathrm{N}$, on two cruises, Quimera-I (October 1996) and Quimera-II (May 1998). The two cruises were carried out on board the R/V García del Cid (38 $\mathrm{m}$ in length, $1500 \mathrm{HP}$ ), and the sampling gear used was an OTMS-27.5 type bottom trawl, towed in a single warp (Sardà et al., 1998).

A total of 39 trawls were taken between depths of 400 and $1714 \mathrm{~m}$ (Table 1, 27 in Quimera-I and 12 in Quimera-II). The effective trawling time ranged from 30 to $60 \mathrm{~min}$ and towing speed was 2.7 knots for all trawls. The arrival and departure of the net to the bottom in addition to the horizontal and vertical openings (14 m and 1.8 to $2 \mathrm{~m}$ respectively) were 
TABLE 1. - Characteristics of hauls (position, mean depth in metres and swept area in hectares) with indications of the total number of species (S), number of individuals (N), and biomass (B) of pelagic and demersal fishes captured on two cruises (Quimera-I, October 1996 and Quimera-II, May 1998) off the south-west Balearic Islands (western Mediterranean), between 400 and $1714 \mathrm{~m}$ depth. N and B are standardised values to a common sampled area of $10000 \mathrm{~m}^{2}$.

\begin{tabular}{|c|c|c|c|c|c|c|c|c|c|c|}
\hline \multirow[t]{2}{*}{ haul } & \multirow[t]{2}{*}{ Date } & \multicolumn{2}{|c|}{ Start position } & \multicolumn{2}{|c|}{ End position } & \multirow{2}{*}{$\begin{array}{c}\text { Mean } \\
\text { depth (m) }\end{array}$} & \multirow{2}{*}{$\begin{array}{c}\text { Swept } \\
\text { area (ha) }\end{array}$} & \multirow[t]{2}{*}{$\mathrm{S}$} & \multirow[t]{2}{*}{$\mathrm{N}$} & \multirow{2}{*}{$\begin{array}{c}\mathrm{B} \\
(\mathrm{kg})\end{array}$} \\
\hline & & Latitude & Longitude & Latitude & Longitude & & & & & \\
\hline QI-1 & $24 / 10 / 96$ & $38^{\circ} 39.36$ & $01^{\circ} 39.72$ & $38^{\circ} 40.31$ & $01^{\circ} 40.91$ & 400 & 3.46 & 22 & 208.90 & 3.67 \\
\hline QI-2 & $24 / 10 / 96$ & $38^{\circ} 39.56$ & $01^{\circ} 40.08$ & $38^{\circ} 40.72$ & $01^{\circ} 41.85$ & 402 & 4.70 & 22 & 104.39 & 2.41 \\
\hline QI-3 & $24 / 10 / 96$ & $38^{\circ} 36.59$ & $01^{\circ} 46.06$ & $38^{\circ} 35.78$ & $01^{\circ} 44.56$ & 502 & 3.72 & 17 & 24.22 & 0.37 \\
\hline QI-4 & $17 / 10 / 96$ & $38^{\circ} 33.69$ & $01^{\circ} 42.67$ & $38^{\circ} 34.19$ & $01^{\circ} 44.15$ & 544 & 3.29 & 17 & 50.76 & 1.44 \\
\hline QI-5 & $23 / 10 / 96$ & $38^{\circ} 36.27$ & $01^{\circ} 52.53$ & $38^{\circ} 37.21$ & $01^{\circ} 53.69$ & 600 & 3.40 & 19 & 40.89 & 0.68 \\
\hline QI-6 & $23 / 10 / 96$ & $38^{\circ} 36.02$ & $01^{\circ} 52.59$ & $38^{\circ} 34.95$ & $01^{\circ} 51.47$ & 601 & 3.60 & 20 & 49.50 & 0.81 \\
\hline QI-7 & $23 / 10 / 96$ & $38^{\circ} 34.69$ & $01^{\circ} 54.19$ & $38^{\circ} 35.47$ & $01^{\circ} 55.74$ & 702 & 3.76 & 18 & 35.93 & 2.01 \\
\hline QI-8 & $22 / 10 / 96$ & $38^{\circ} 31.47$ & $01^{\circ} 49.19$ & $38^{\circ} 30.80$ & $01^{\circ} 47.87$ & 700 & 3.21 & 20 & 50.81 & 2.97 \\
\hline QI-9 & $22 / 10 / 96$ & $38^{\circ} 30.18$ & $01^{\circ} 49.18$ & $38^{\circ} 29.23$ & $01^{\circ} 47.81$ & 803 & 3.73 & 22 & 35.40 & 7.74 \\
\hline QI-10 & $22 / 10 / 96$ & $38^{\circ} 28.78$ & $01^{\circ} 47.07$ & $38^{\circ} 29.56$ & $01^{\circ} 48.42$ & 816 & 3.42 & 20 & 34.21 & 10.08 \\
\hline QI-11 & $23 / 10 / 96$ & $38^{\circ} 31.25$ & $01^{\circ} 58.27$ & $38^{\circ} 31.23$ & $01^{\circ} 56.40$ & 900 & 3.82 & 18 & 37.69 & 8.71 \\
\hline QI-12 & $23 / 10 / 96$ & $38^{\circ} 31.19$ & $01^{\circ} 56.36$ & $38^{\circ} 31.05$ & $01^{\circ} 57.87$ & 904 & 3.11 & 13 & 38.63 & 6.32 \\
\hline QI-13 & $18 / 10 / 96$ & $38^{\circ} 26.89$ & $01^{\circ} 51.34$ & $38^{\circ} 28.83$ & $01^{\circ} 53.86$ & 1013 & 7.20 & 16 & 30.01 & 7.11 \\
\hline QI-14 & $18 / 10 / 96$ & $38^{\circ} 28.04$ & $01^{\circ} 53.48$ & $38^{\circ} 26.50$ & $01^{\circ} 50.98$ & 1022 & 6.48 & 12 & 39.79 & 7.56 \\
\hline QI-15 & $18 / 10 / 96$ & $38^{\circ} 25.79$ & $01^{\circ} 55.44$ & $38^{\circ} 24.35$ & $01^{\circ} 55.25$ & 1100 & 3.75 & 12 & 40.49 & 9.63 \\
\hline QI-16 & $22 / 10 / 96$ & $38^{\circ} 25.93$ & $01^{\circ} 55.72$ & $38^{\circ} 27.14$ & $01^{\circ} 56.64$ & 1118 & 3.66 & 14 & 36.64 & 7.88 \\
\hline QI-17 & $19 / 10 / 96$ & $38^{\circ} 24.48$ & $01^{\circ} 47.33$ & $38^{\circ} 25.32$ & $01^{\circ} 46.13$ & 1211 & 3.28 & 10 & 30.80 & 8.40 \\
\hline QI-18 & $19 / 10 / 96$ & $38^{\circ} 23.87$ & $01^{\circ} 48.42$ & $38^{\circ} 22.94$ & $01^{\circ} 49.79$ & 1234 & 3.69 & 13 & 36.27 & 6.98 \\
\hline QI-19 & $19 / 10 / 96$ & $38^{\circ} 22.78$ & $01^{\circ} 45.06$ & $38^{\circ} 22.56$ & $01^{\circ} 48.36$ & 1306 & 6.77 & 13 & 31.63 & 7.80 \\
\hline QI-20 & $19 / 10 / 96$ & $38^{\circ} 19.75$ & $01^{\circ} 47.04$ & $38^{\circ} 19.86$ & $01^{\circ} 45.15$ & 1407 & 3.87 & 11 & 21.44 & 3.64 \\
\hline QI-21 & $21 / 10 / 96$ & $38^{\circ} 19.58$ & $01^{\circ} 46.77$ & $38^{\circ} 19.65$ & $01^{\circ} 48.44$ & 1418 & 3.42 & 12 & 30.73 & 3.73 \\
\hline QI-22 & $20 / 10 / 96$ & $38^{\circ} 16.00$ & $01^{\circ} 48.35$ & $38^{\circ} 15.06$ & $01^{\circ} 49.76$ & 1500 & 3.77 & 12 & 27.30 & 2.83 \\
\hline QI-23 & $21 / 10 / 96$ & $38^{\circ} 16.22$ & $01^{\circ} 47.75$ & $38^{\circ} 16.82$ & $01^{\circ} 46.19$ & 1503 & 3.55 & 12 & 48.21 & 4.00 \\
\hline QI-24 & $21 / 10 / 96$ & $38^{\circ} 12.95$ & $01^{\circ} 47.72$ & $38^{\circ} 12.42$ & $01^{\circ} 49.50$ & 1600 & 3.89 & 12 & 37.04 & 3.61 \\
\hline QI-25 & $20 / 10 / 96$ & $38^{\circ} 12.81$ & $01^{\circ} 47.99$ & $38^{\circ} 13.25$ & $01^{\circ} 46.42$ & 1602 & 3.40 & 11 & 12.04 & 0.42 \\
\hline QI-26 & $20 / 10 / 96$ & $38^{\circ} 08.09$ & $01^{\circ} 41.86$ & $38^{\circ} 09.54$ & $01^{\circ} 41.86$ & 1709 & 3.76 & 12 & 38.83 & 4.30 \\
\hline QI-27 & $20 / 10 / 96$ & $38^{\circ} 07.34$ & $01^{\circ} 42.03$ & $38^{\circ} 05.91$ & $01^{\circ} 41.98$ & 1714 & 3.71 & 14 & 43.41 & 3.67 \\
\hline QII-1 & $09 / 05 / 98$ & $38^{\circ} 36.15$ & $01^{\circ} 37.98$ & $38^{\circ} 37.10$ & $01^{\circ} 38.65$ & 415 & 2.81 & 18 & 44.82 & 1.22 \\
\hline QII-2 & $08 / 05 / 98$ & $38^{\circ} 35.03$ & $01^{\circ} 41.77$ & $38^{\circ} 35.62$ & $01^{\circ} 40.28$ & 529 & 3.38 & 18 & 45.57 & 1.93 \\
\hline QIII-3 & 08/05/98 & $38^{\circ} 32.03$ & $01^{\circ} 47.25$ & $38^{\circ} 32.13$ & $01^{\circ} 45.22$ & 626 & 4.11 & 14 & 38.41 & 1.50 \\
\hline QII-4 & 08/05/98 & $38^{\circ} 30.32$ & $01^{\circ} 40.93$ & $38^{\circ} 30.82$ & $01^{\circ} 39.48$ & 710 & 3.21 & 17 & 38.99 & 1.17 \\
\hline QII-5 & $08 / 05 / 98$ & $38^{\circ} 29.17$ & $01^{\circ} 40.72$ & $38^{\circ} 29.90$ & $01^{\circ} 38.98$ & 813 & 4.00 & 19 & 17.27 & 2.75 \\
\hline QII-6 & $09 / 05 / 98$ & $38^{\circ} 31.22$ & $01^{\circ} 55.67$ & $38^{\circ} 31.18$ & $01^{\circ} 57.87$ & 908 & 4.45 & 15 & 31.91 & 6.70 \\
\hline QII-7 & $07 / 05 / 98$ & $38^{\circ} 28.47$ & $01^{\circ} 54.00$ & $38^{\circ} 26.80$ & $01^{\circ} 51.65$ & 1032 & 6.43 & 13 & 24.42 & 6.78 \\
\hline QII-8 & $10 / 05 / 98$ & $38^{\circ} 26.60$ & $01^{\circ} 47.65$ & $38^{\circ} 26.02$ & $01^{\circ} 49.55$ & 1129 & 4.13 & 14 & 25.93 & 4.75 \\
\hline QII-9 & $10 / 05 / 98$ & $38^{\circ} 22.42$ & $01^{\circ} 47.02$ & $38^{\circ} 22.67$ & $01^{\circ} 45.08$ & 1322 & 3.98 & 15 & 18.36 & 3.54 \\
\hline QII-10 & $10 / 05 / 98$ & $38^{\circ} 19.78$ & $01^{\circ} 46.42$ & $38^{\circ} 19.95$ & $01^{\circ} 50.23$ & 1416 & 7.72 & 14 & 25.78 & 5.31 \\
\hline QIII-11 & $11 / 05 / 98$ & $38^{\circ} 16.25$ & $01^{\circ} 47.50$ & $38^{\circ} 15.15$ & $01^{\circ} 49.68$ & 1513 & 5.25 & 13 & 37.14 & 3.03 \\
\hline QII-12 & $11 / 05 / 98$ & $38^{\circ} 12.25$ & $01^{\circ} 49.82$ & $38^{\circ} 13.45$ & $01^{\circ} 46.10$ & 1622 & 8.14 & 10 & 27.39 & 0.89 \\
\hline
\end{tabular}

measured using the SCANMAR system. The cod end mesh size was $12 \mathrm{~mm}$. For each haul individual fish were counted, the total weight of the catch was calculated as the sum of fresh weights of each species, and all demersal fish collected were measured. Abundance and biomass were standardised to a common sampled area of $10000 \mathrm{~m}^{2}$ from the exact area swept by the trawl calculated from the SCANMAR system.

\section{Multivariate analysis of assemblage structure}

In order to determine whether any pair of samples had been taken at sites too closely located to each other (and therefore could not be considered independent), we built up a semivariogram (Legendre and Legendre, 1998) with the sample values on the second axis from detrended canonical correspondence analyses (DCCA), using depth as an explanatory variable. This preliminary semivariogram showed that distances between some pairs of samples were too small (Fig. 1a). Consequently, only one of the two samples from these pairs was considered. This reduced data set was free of spatial autocorrelation and was used for all multivariate testing procedures (Fig. 1b). Pelagic and rare species (species appearing less than three times) were excluded from the analysis (Table 2).

Between-cruise differences of demersal species composition, both in standardised abundance and biomass, were tested using partial detrended canonical correspondence analyses, pDCCA (ter Braak and Smilauer, 1998).

To analyse the spatial variations related to depth, the data were grouped into three depth intervals: upper slope 400-800 m, middle slope 801-1400 m 

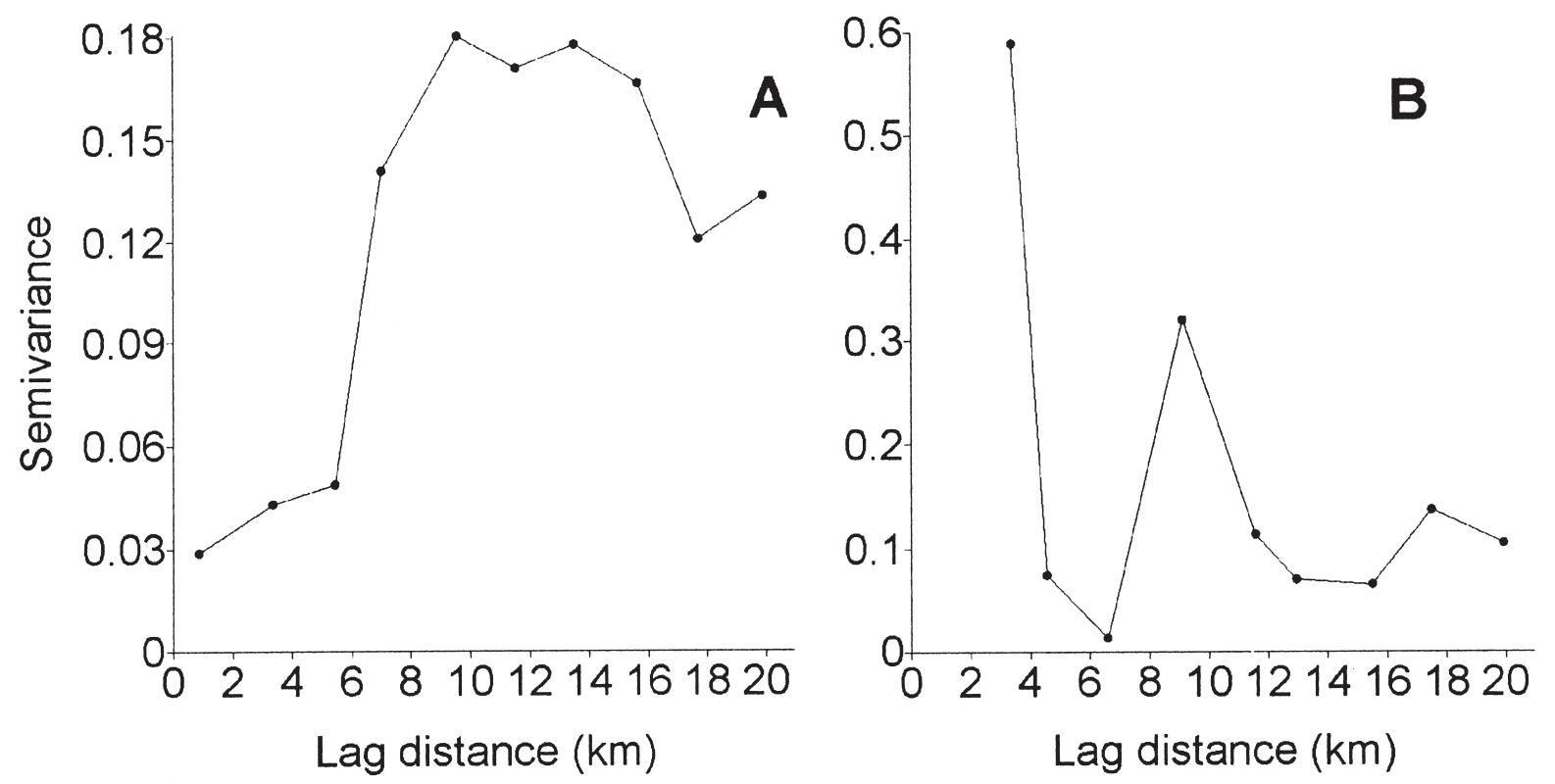

FIG. 1. - Semivariograms (plots of the faunistic variability of the hauls placed within predefined lags of geographic distance). In order to focus the effects of geographic distance only, the second axis from a DCCA (depth being the explanatory variable) was considered as the estimator of faunistic similarity. Panel A shows the semivariogram of all possible pairs of hauls taken on the Quimera-I cruise, and demonstrates that hauls placed very close to each other tend to be very similar, suggesting the existence of spatial autocorrelation (left part of the semivariogram). Panel B shows the semivariogram corresponding to a reduced data set (one of the two hauls taken at the same depth stratum was removed;

Table 1), and suggests that the problem of spatial autocorrelation was largely ameliorated. Note that the vertical scales are different.

and lower slope 1401-1714 m. These depth strata correspond to the different fish assemblages identified previously in the same study area (Moranta et al., 1998).

The PRIMER package was used to analyse the standardised abundance and biomass matrices of species by samples (Clarke and Green, 1988). Analysis of similitude (ANOSIM) and similarity percentage analysis (SIMPER) were also applied to detect between-cruise or bathymetric differences. The ANOSIM test is based on a simple non-parametric permutation procedure (999 permutations), applied to the rank similarity matrix, and is combined with a general randomisation approach to the generation of significance levels (Monte Carlo tests; Hope, 1968). The SIMPER test is a statistical breakdown of Bray-Curtis dissimilarity into contributions for each species in each of the groups compared.

\section{Ecological parameters}

Species richness (number of species), abundance (number of individuals), biomass (g) and Shannon diversity index were determined for each haul. Only pelagic species were excluded from the computation of these assemblage descriptors (Table 2). Between cruises (Quimera-I vs. Quimera-II) and between assemblages (upper, middle and lower slope as pre-
TABLE 2. - List of pelagic and demersal species captured on both cruises (Quimera-I, October 1996, and Quimera-II, May 1998) not considered in multifactorial analysis ( $\mathrm{N}$, number of hauls; W, weight).

\begin{tabular}{|c|c|c|c|}
\hline & $\mathrm{N}$ & Individuals & $\mathrm{W}(\mathrm{g})$ \\
\hline \multicolumn{4}{|l|}{ Pelagic species } \\
\hline Lampanyctus crocodilus & 34 & 430 & 3544 \\
\hline Argyropelecus hemigymnus & 33 & 83 & 66 \\
\hline Stomias boa & 17 & 35 & 224 \\
\hline Chauliodus sloani & 16 & 20 & 714 \\
\hline Laemonema sp. & 13 & 123 & 1743 \\
\hline Benthosema glaciale & 11 & 31 & 27 \\
\hline Paraliparis leptochirus & 8 & 9 & 11 \\
\hline Cyclothone braueri & 7 & 25 & 20 \\
\hline Notolepis rissoi & 6 & 6 & 11 \\
\hline Cyclothone pygmaea & 5 & 14 & 11 \\
\hline Myctophum punctatum & 3 & 16 & 20 \\
\hline Notoscopelus elongatus & 3 & 26 & 23 \\
\hline Borostomias antarcticus & 1 & 1 & 5 \\
\hline Capros aper & 1 & 1 & 2 \\
\hline Centrolophus niger & 1 & 1 & 3000 \\
\hline Ceratoscopelus maderensis & 1 & 1 & 2 \\
\hline Dysomma brevirostre & 1 & 1 & 44 \\
\hline Electrona rissoi & 1 & 1 & 3 \\
\hline Maurolicus muelleri & 1 & 1 & 1 \\
\hline Nemichthys scolopaceus & 1 & 1 & 13 \\
\hline Regalecus glesne & 1 & 1 & 220 \\
\hline Symbolophorus veranyi & 1 & 2 & 2 \\
\hline \multicolumn{4}{|l|}{ Demersal species } \\
\hline Cataetyx laticeps & 2 & 3 & 671 \\
\hline Scyliorhinus canicula & 2 & 3 & 737 \\
\hline Trigla lyra & 2 & 2 & 25 \\
\hline Centrophorus uyato & 1 & 1 & 4000 \\
\hline Lophius budegassa & 1 & 1 & 367 \\
\hline Peristedion cataphractum & 1 & 1 & 20 \\
\hline Raja naevus & 1 & 1 & 669 \\
\hline Raja polystigma & 1 & 1 & 220 \\
\hline Scorpaena elongata & 1 & 1 & 366 \\
\hline
\end{tabular}


TABLE 3. - Classification of the main demersal species captured on both cruises related to their preferred optimum depth (expressed as a centre of gravity) from Moranta et al. (1998). Only those species with the centre of gravity within the depth range surveyed were considered.

\begin{tabular}{|c|c|c|}
\hline Upper slope (400-800 m) & Middle slope (801-1400 m) & Lower slope (1401-1714 m) \\
\hline $\begin{array}{l}\text { Gaidropsarus biscayensis } \\
\text { Dalatias licha } \\
\text { Galeus melastomus } \\
\text { Hoplostethus mediterraneus } \\
\text { Hymenocephalus italicus } \\
\text { Micromesistius poutassou } \\
\text { Phycis blennoides } \\
\text { Symphurus ligulatus }\end{array}$ & $\begin{array}{l}\text { Alepocephalus rostratus } \\
\text { Cataetyx alleni } \\
\text { Conger conger } \\
\text { Epigonus telescopus } \\
\text { Etmopterus spinax } \\
\text { Mora moro } \\
\text { Nettastoma melanurum } \\
\text { Nezumia aequalis } \\
\text { Notacanthus bonapartei } \\
\text { Trachyrincus scabrus }\end{array}$ & $\begin{array}{l}\text { Bathypterois mediterraneus } \\
\text { Caelorinchus labiatus } \\
\text { Centroscymnus coelolepis } \\
\text { Chalinura mediterranea } \\
\text { Coryphaenoides guentheri } \\
\text { Lepidion guentheri } \\
\text { Lepidion lepidion } \\
\text { Polyacanthonotus rissoanus }\end{array}$ \\
\hline
\end{tabular}

established groups) differences for these ecological parameters were tested using two-factor analysis of variance (ANOVA).

Sample size (area swept) was not the same in each haul (Table 1; mean $=4.2$ ha; sd $=1.3$; range: 2.8 to 8.1 ). However, as shown by a multivariate regression analysis on depth and sample size, neither the species richness nor the diversity were affected by this last factor. Thus, the partial effect of sample size was non-significant $(\mathrm{P}=0.43$ for species richness, and $\mathrm{P}=0.24$ for species diversity), so no correction for sample size was applied.

\section{Size spectra and mean body size}

The individual weights of each specimen were calculated from specific length-weight relationships obtained from the authors' own unpublished data or from bibliographic sources (e.g. Merella et al., 1997; Morey et al., 2003).

To calculate the mean species biomass of each assemblage, species were assigned into one of the three pre-established assemblages (upper, middle or lower slope), according to its optimum depth, estimated from the centre of gravity. This information was already known in the study area (see Moranta $e t$ al., (1998) and Table 3). Finally, differences between assemblages in mean body mass were assessed by a one-factor (depth) analysis of variance (ANOVA).

Biomass spectra were calculated for each of the pre-established fish assemblages. Fish bigger than 1 $\mathrm{g}$ were assigned to $\log _{2}$ body-mass class, and cumulative biomass in each body-mass class was calculated. Normalised biomass size spectra were computed dividing the biomass in a given body mass class interval by the width of that class interval (in antilog dimensions). Between-assemblage differences in biomass spectra were tested using repeated
ANOVA measures. Each individual haul was considered as an observation, and the repeated measures were the normalised biomass corresponding to each of the $\log _{2}$ categories. The normalised data were $\ln (x+1)$ transformed to adjust residuals to normality.

Mean body mass per haul was plotted over a depth axis to display related trends with this variable (depth). Furthermore, mean maximum body mass per haul was also calculated averaging the maximum body mass of each species in each haul. The relationships between depth and both abundance and mean $\log _{2}$ body mass at species level were fitted to a generalised linear model (covering Gaussian and logistic models) and to a linear model respectively.

\section{RESULTS}

\section{Between-cruises comparisons}

The specific composition of each cruise is shown in Table 4. Six species (Galeus melastomus, Alepocephalus rostratus, Nezumia aequalis, Bathypterois mediterraneus, Phycis blennoides and Mora moro) represented more than 70 and $85 \%$ of the total abundance and biomass in both cruises respectively. Three species (Symphurus nigrescens, Epigonus denticulatus and Lepidopus caudatus) had a major contribution in the Quimera-I cruise and another three species (Epigonus telescopus, Helicolenus dactylopterus and Trachyrincus scabrus) were more important in the Quimera-II cruise.

The partial (detrended) correspondence canonical analysis conducted on the reduced data set showed that between-cruise differences were nonsignificant considering either the number of individuals $($ Trace $=0.06 ;$ F-ratio $=1.03 ; \mathrm{P}=0.37$ ) or the 
TABLE 4. - Demersal fish species collected on two cruises (Quimera-I, October 1996, and Quimera-II, May 1998) off the south-west Balearic Islands (western Mediterranean) in 39 valid hauls from 400 to $1714 \mathrm{~m}$ depth. Only those species with a frequency of appearance (F) greater than $15 \%$ are listed. The depth range in which the species appeared is also indicated. (A, abundance; B, biomass).

\begin{tabular}{|c|c|c|c|c|c|c|c|c|c|}
\hline Quimera-I (October, 1996) & $\mathrm{F}(\%)$ & $\mathrm{A}(\%)$ & $\mathrm{B}(\%)$ & $\begin{array}{c}\text { Depth } \\
\text { range }(\mathrm{m})\end{array}$ & Quimera-II (May, 1998) & $\mathrm{F}(\%)$ & $\mathrm{A}(\%)$ & $\mathrm{B}(\%)$ & $\begin{array}{l}\text { Depth } \\
\text { range }(\mathrm{m})\end{array}$ \\
\hline Galeus melastomus & 74.07 & 10.43 & 12.32 & $400-1714$ & Galeus melastomus & 91.67 & 7.12 & 15.55 & $415-1513$ \\
\hline Alepocephalus rostratus & 66.67 & 15.03 & 39.00 & $700-1714$ & Alepocephalus rostratus & 66.67 & 16.65 & 37.96 & $813-1622$ \\
\hline Nezumia aequalis & 66.67 & 10.95 & 2.91 & $502-1407$ & Etmopterus spinax & 66.67 & 3.06 & 1.79 & $415-1416$ \\
\hline Bathypterois mediterraneus & 55.56 & 10.09 & 0.62 & $1013-1714$ & Nezumia aequalis & 66.67 & 14.15 & 3.24 & $529-1322$ \\
\hline Etmopterus spinax & 55.56 & 0.99 & 2.17 & 502-1306 & Bathypterois mediterraneus & 58.33 & 15.59 & 0.74 & $908-1622$ \\
\hline Caelorinchus labiatus & 51.85 & 2.91 & 0.48 & $1013-1714$ & Nettastoma melanurum & 58.33 & 1.48 & 0.95 & $415-1416$ \\
\hline Phycis blennoides & 51.85 & 16.22 & 6.79 & 400-1022 & Phycis blennoides & 58.33 & 13.89 & 5.61 & $415-1032$ \\
\hline Lepidion lepidion & 48.15 & 1.23 & 1.26 & $1013-1714$ & Hoplostethus mediterraneus & 50.00 & 2.57 & 1.08 & $529-1322$ \\
\hline Nettastoma melanurum & 48.15 & 0.70 & 0.57 & $700-1234$ & Lepidion lepidion & 50.00 & 1.44 & 1.67 & $908-1622$ \\
\hline Mora moro & 44.44 & 5.06 & 25.31 & $700-1234$ & Notacanthus bonapartei & 50.00 & 0.80 & 0.07 & $626-1513$ \\
\hline Hymenocephalus italicus & 40.74 & 3.22 & 0.27 & $402-900$ & Chalinura mediterranea & 41.67 & 3.03 & 0.16 & $1129-1622$ \\
\hline Chalinura mediterranea & 37.04 & 3.55 & 0.24 & $1100-1714$ & Caelorinchus labiatus & 41.67 & 1.90 & 0.22 & $1129-1622$ \\
\hline Gaidropsarus biscayensis & 33.33 & 0.75 & 0.02 & $400-803$ & Hymenocephalus italicus & 41.67 & 5.14 & 0.30 & $415-813$ \\
\hline Centroscymnus coelolepis & 33.33 & 0.70 & 3.14 & $1013-1714$ & Mora moro & 33.33 & 5.30 & 24.58 & $813-1129$ \\
\hline Hoplostethus mediterraneus & 33.33 & 1.73 & 0.63 & 502-1118 & Symphurus ligulatus & 33.33 & 2.04 & 0.04 & $529-813$ \\
\hline Notacanthus bonapartei & 33.33 & 0.34 & 0.12 & $600-1418$ & Centroscymnus coelolepis & 25.00 & 0.44 & 1.50 & $1416-1622$ \\
\hline Symphurus ligulatus & 33.33 & 2.40 & 0.05 & $502-900$ & Polyacanthonotus rissoanus & 25.00 & 0.50 & 0.01 & 813-1622 \\
\hline Polyacanthonotus rissoanus & 29.63 & 0.43 & 0.05 & $700-1709$ & Gaidropsarus biscayensis & 16.67 & 0.42 & 0.02 & $415-529$ \\
\hline Symphurus nigrescens & 22.22 & 1.50 & 0.08 & $400-601$ & Cataetyx alleni & 16.67 & 0.08 & 0.01 & $1416-1622$ \\
\hline Cataetyx alleni & 18.52 & 0.16 & 0.01 & $700-1500$ & Epigonus telescopus & 16.67 & 0.31 & 0.41 & $415-813$ \\
\hline Epigonus denticulatus & 18.52 & 0.13 & 0.01 & $400-600$ & Helicolenus dactylopterus & 16.67 & 0.43 & 0.14 & $415-529$ \\
\hline Lepidopus caudatus & 18.52 & 0.20 & 0.13 & $400-601$ & Merluccius merluccius & 16.67 & 0.30 & 0.65 & $415-529$ \\
\hline Merluccius merluccius & 18.52 & 0.73 & 1.26 & $400-803$ & Micromesistius poutassou & 16.67 & 1.91 & 2.45 & $415-529$ \\
\hline Micromesistius poutassou & 18.52 & 0.34 & 0.47 & $400-816$ & Trachyrinchus scabrus & 16.67 & 0.18 & 0.22 & $710-913$ \\
\hline
\end{tabular}

biomass $($ Trace $=0.04 ;$ F-ratio $=0.66 ; \mathrm{P}=0.83$ ). Note that tested differences should only be attributed to between-cruises because the samples had been statistically adjusted in order to avoid the depth effect.

The analysis of similarity (ANOSIM) also showed non-significant between-cruise differences (Table 5). Similarly, no significant differences were obtained for the ecological parameters (number of species $\mathrm{F}_{1,33}=$ $1.97, \mathrm{P}>0.05$; individuals $\mathrm{F}_{1,33}=3.15, \mathrm{P}>0.05$; biomass $\mathrm{F}_{1,33}=0.66, \mathrm{P}>0.05$ and diversity $\mathrm{F}_{1,33}=1.10$, $\mathrm{P}>0.05)$. Only in the case of the number of species a significant interaction between cruise and depth was obtained $\left(\mathrm{F}_{1,33}=4.35, \mathrm{P}<0.05\right)$.

Assuming that there are no between-cruise differences, the data from the two cruises were pooled for subsequent analysis.

\section{Bathymetric variations in assemblage structure}

The analysis of similarity (ANOSIM) confirmed significant differences between assemblages related to depth (Table 5). These assemblages appeared to be very well defined since the dissimilarity between them was very high (Table 6).

The mean values of the ecological parameters of each assemblage are represented in Figure 2. Species richness decreased with depth. The highest value (an average of 13.3 species) was found on the upper slope, followed by the middle (10.8 species) and the lower slope (8.6 species). There was a significant difference between assemblages $\left(\mathrm{F}_{2,33}=\right.$ $6.37 ; \mathrm{P}<0.01)$, and post-hoc tests showed significant differences in all pair-wise combinations $(\mathrm{P}<$ $0.05)$. Non-significant differences were detected in the case of abundance $\left(\mathrm{F}_{2,33}=1.71 ; \mathrm{P}=0.20\right)$, average values ranging between 38.09 and 26.05 individuals for the upper and lower slope respectively. For the biomass, the middle slope had a higher value $(6.97 \mathrm{~kg})$ than either the upper $(1.33 \mathrm{~kg})$ or the lower slope $(2.77 \mathrm{~kg})\left(\mathrm{F}_{2.33}=18.29 ; \mathrm{P}<0.001\right)$. Moreover, clear differences between them were detected in post-hoc pair-wise comparisons $(\mathrm{P}<0.001)$.

TABLE 5. - Results of the ANOSIM routine to analyse differences between cruises (Quimera-I, October 1996 and Quimera-II, May 1998) and depths, considering the pre-established groups resulting from Moranta et al. (1998): US, upper slope (400-800 m); MS, middle slope (801-1400 m); LS, lower slope (1401-1714 m); R, ANOSIM statistic; $\mathrm{P}$, significance.

\begin{tabular}{|c|c|c|c|c|}
\hline \multirow[b]{2}{*}{ Comparison } & \multicolumn{2}{|c|}{ Abundance } & \multicolumn{2}{|c|}{ Biomass } \\
\hline & $\mathrm{R}$ & $\mathrm{P}$ & $\mathrm{R}$ & $\mathrm{P}$ \\
\hline \multicolumn{5}{|l|}{ Between cruises } \\
\hline Q-I vs Q-II & -0.04 & 0.62 & -0.13 & 0.94 \\
\hline Between depth & 0.85 & 0.01 & 0.87 & 0.01 \\
\hline US vs MS & 0.74 & 0.01 & 0.78 & 0.01 \\
\hline US vs LS & 1.00 & 0.01 & 1.00 & 0.01 \\
\hline MS vs LS & 0.89 & 0.01 & 0.89 & 0.01 \\
\hline
\end{tabular}


TABLE 6. - Results of the SIMPER routine to analyse dissimilarity between pre-established depth groups from Moranta et al. 1998 (upper slope, $400-800 \mathrm{~m}$; middle slope, $801-1400 \mathrm{~m}$; lower slope, 1401-1714 m) for the number of individuals and biomass. Only the highest contributing species are represented. $\bar{\delta}_{i}$, average dissimilarity; SD, standard deviation.

\begin{tabular}{|c|c|c|c|c|c|c|c|}
\hline \multirow[b]{2}{*}{ Species } & \multicolumn{3}{|c|}{ Number of individuals } & \multirow[b]{2}{*}{ Species } & \multicolumn{3}{|c|}{ Biomass } \\
\hline & $\bar{\delta}_{i}$ & $\bar{\delta}_{i} / \mathrm{SD}$ & $\sum \bar{\delta}_{i} \%$ & & $\bar{\delta}_{i}$ & $\bar{\delta}_{i} / \mathrm{SD}$ & $\Sigma \bar{\delta}_{i} \%$ \\
\hline Upper slope vs Middle slope & 78.66 & & & & 85.25 & & \\
\hline Phycis blennoides & 15.68 & 1.50 & 19.93 & Mora moro & 8.04 & 1.62 & 32.89 \\
\hline Alepocephalus rostratus & 13.48 & 1.45 & 37.06 & Alepocephalus rostratus & 6.35 & 1.30 & 63.80 \\
\hline Nezumia aequalis & 6.44 & 1.34 & 56.41 & Galeus melastomus & 8.84 & 1.14 & 74.17 \\
\hline Mora moro & 8.78 & 1.54 & 48.22 & Phycis blennoides & 5.52 & 1.35 & 80.65 \\
\hline Galeus melastomus & 5.31 & 0.79 & 63.16 & & & & \\
\hline Upper slope vs Lower slope & 99.15 & & & & 97.86 & & \\
\hline Bathypterois mediterraneus & 19.66 & 4.53 & 12.25 & Alepocephalus rostratus & 47.20 & 2.71 & 48.24 \\
\hline Phycis blennoides & 17.08 & 3.24 & 23.06 & Phycis blennoides & 9.98 & 1.41 & 58.44 \\
\hline Alepocephalus rostratus & 9.52 & 2.88 & 31.73 & Galeus melastomus & 9.49 & 0.90 & 68.14 \\
\hline Nezumia aequalis & 7.18 & 0.76 & 53.90 & Centroscymnus coelolepis & 6.69 & 0.96 & 74.98 \\
\hline Galeus melastomus & 6.56 & 0.93 & 60.51 & Lepidion lepidion & 4.07 & 1.91 & 19.13 \\
\hline Middle slope vs Lower slope & 77.15 & & & & 69.47 & & \\
\hline Bathypterois mediterraneus & 20.98 & 2.54 & 27.20 & Mora moro & 23.97 & 1.57 & 34.51 \\
\hline Nezumia aequalis & 12.19 & 2.14 & 43.00 & Alepocephalus rostratus & 17.69 & 25.47 & 59.98 \\
\hline Alepocephalus rostratus & 10.24 & 1.31 & 56.27 & Galeus melastomus & 8.79 & 1.32 & 72.64 \\
\hline Mora moro & 7.45 & 1.49 & 65.93 & Centroscymnus coelolepis & 3.27 & 0.95 & 77.35 \\
\hline Chalinura mediterranea & 6.35 & 1.28 & 77.08 & & & & \\
\hline
\end{tabular}
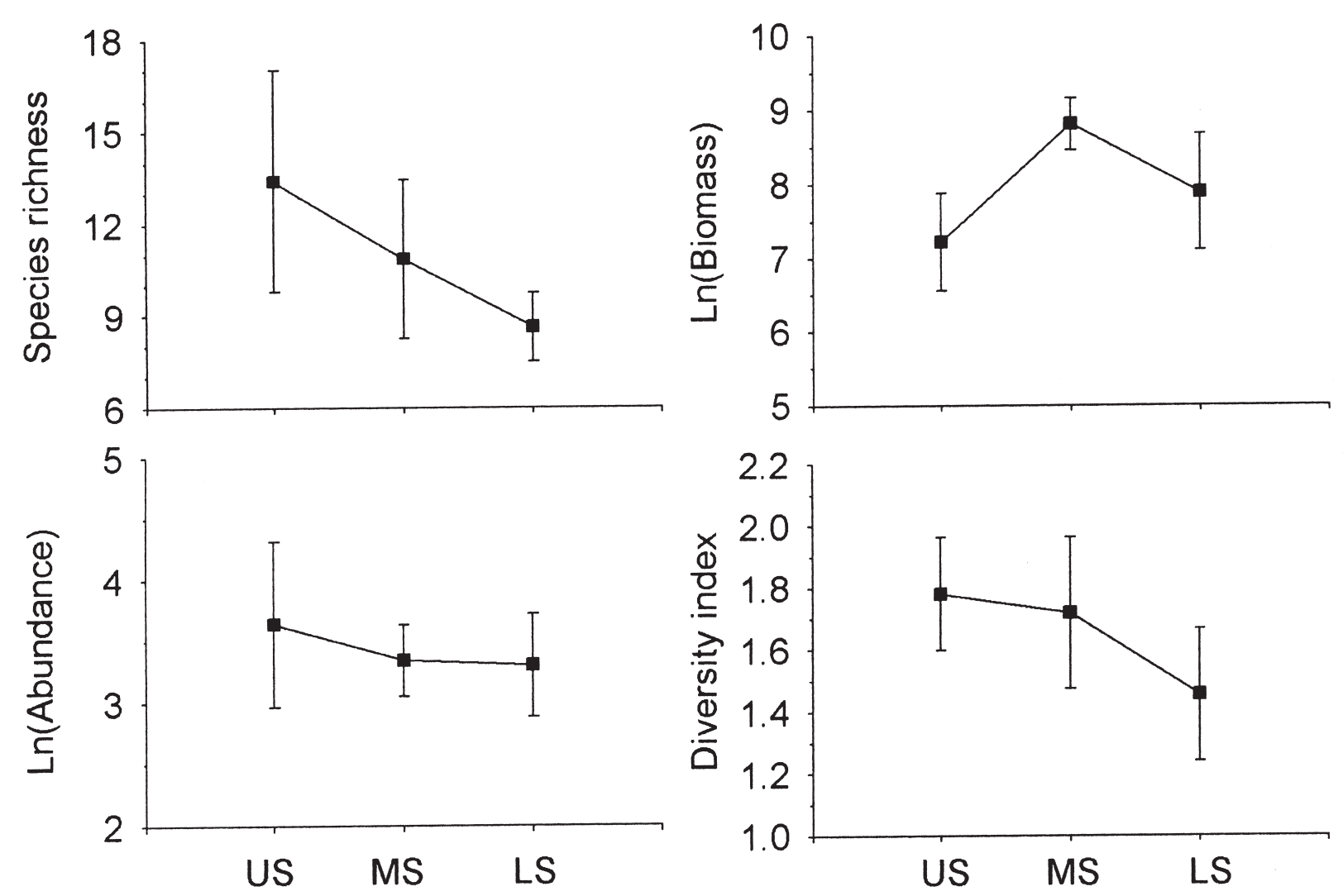

FIG. 2. - Variation of the ecological parameters (number of species, number of individuals, biomass and diversity) in the pre-established depth intervals: US, upper slope 400-800 m; MS, middle slope 801-1400 m; and LS, lower slope 1401-1714 m from Moranta et al. (1998).

Diversity followed a similar pattern to species richness $\left(\mathrm{F}_{2,33}=6.36 ; \mathrm{P}<0.01\right)$, but a non-significant difference $(\mathrm{P}=0.45)$ was found in a post-hoc comparison between the upper slope and the middle slope (1.78 vs. 1.71$)$.
The contribution of each size class to the total biomass showed significant differences between the three assemblages $\left(\mathrm{F}_{18,287}=17.398 ; \mathrm{P}<0.001 ;\right.$ Fig. 3$)$. The upper slope was characterised by an important fraction of the biomass $(93 \%)$ below $2^{6}(64 \mathrm{~g})$ size 


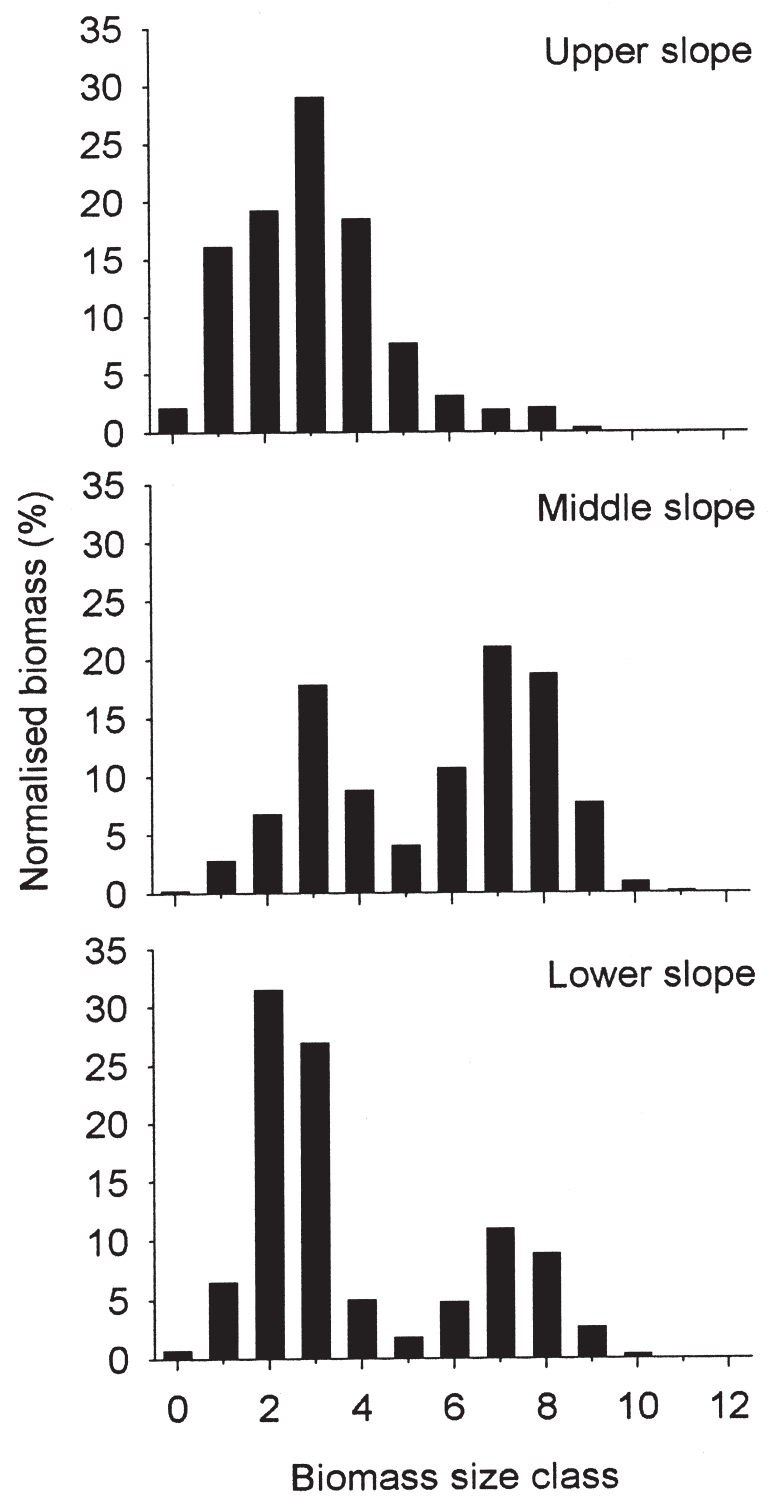

FIG. 3. - Normalised biomass spectra of the three demersal fish assemblages: upper slope, 400-800 m; middle slope, 801-1400 m; and lower slope, 1401-1714 m. The biomass size class correspond to the $\log _{2}$ of weight.

class. Small classes also predominated in the deepest assemblage with $66 \%$ of the biomass concentrated below $2^{4}(16 \mathrm{~g})$ size class. In this assemblage a second mode was detected at $2^{7}(128 \mathrm{~g})$. The biomass of the middle slope was divided into two groups, below $2^{5}$ $(32 \mathrm{~g})$ and greater than this size class, with 41 and $59 \%$ of the total biomass respectively.

\section{Depth related trends in body mass}

The mean species biomass of each assemblage, according to their optimum depth, did not show significant differences $\left(\mathrm{F}_{2,22}=1.16 ; \mathrm{P}=0.33\right.$; Fig. 4$)$. In contrast, the distribution of mean body mass per haul

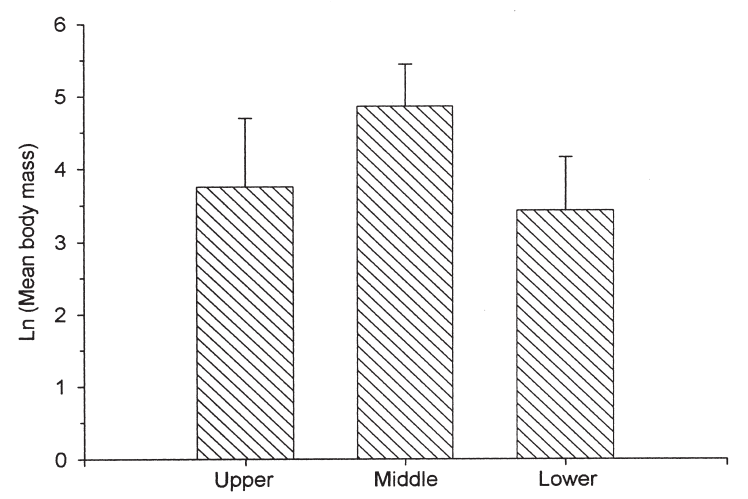

FIG. 4. - Mean body mass of the three assemblages (US, upper slope; MS, middle slope; LS, lower slope). The mean body mass of each assemblage was calculated averaging the biomass of the different species between all hauls in which the species was present To arrange single species into one of the three depth intervals the optimum depth preferred for each species was fitted considering the centre of gravity, previously reported by Moranta et al. (1998) (see Table 3 and text for more details).

exhibited a broad peak between 800 and $1322 \mathrm{~m}$ (Fig. 5a), coincident with the biomass peak described for the ecological parameters, while in the mean maximum body mass this peak was not so marked, with an increase from 400 to $1000 \mathrm{~m}$ depth and two different groups of size below this depth (Fig. 5b).
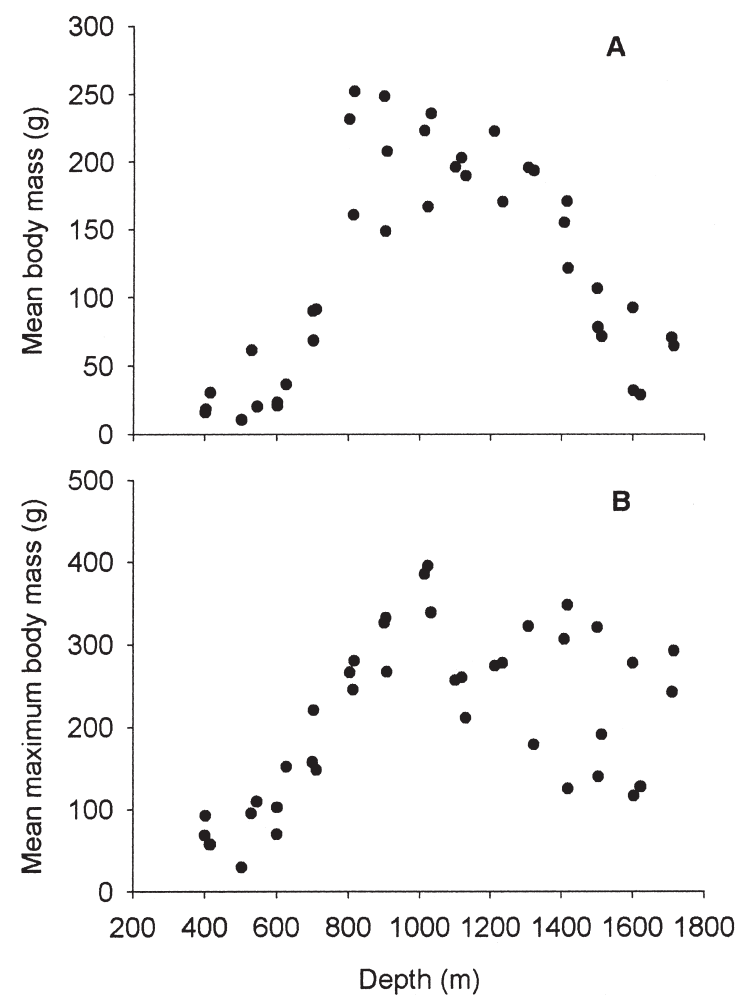

FIG. 5. - Trends in the mean body mass and mean maximum body mass of demersal species in the community sampled between 400 and $1714 \mathrm{~m}$ depth. The data from the two cruises (Quimera-I, October 1996 and Quimera-II, May 1998) are pooled, implicitly assuming that there are no between-cruise differences (see text for more details). 
TABLE 7. - Results for the relationship between $\log _{2}$ body mass (linear regression) and abundance (unimodal or linear responses) and depth of the main demersal species captured between 400 and $1714 \mathrm{~m}$ depth on the two cruises, Quimera-I and Quimera-II. The 23 species listed below accounted for more than 80 and $90 \%$ of the total abundance and biomass respectively. Response type (Rt) indicates the most parsimonious model selected by the AIC criterion (unimodal, linear or non-significant, n.s.). In the case of abundance, the model parameters were obtained by maximising likelihood. Opt/R indicates the optimum depth (Opt) in metres, in the cases of unimodal responses $\left({ }^{a}\right)$ or the regression coefficient in the case of linear responses $\left({ }^{b}\right)$. $n$, number of hauls; $R$, regression coefficient; $P$, significance.

\begin{tabular}{|c|c|c|c|c|c|c|}
\hline \multirow[t]{2}{*}{ Species } & \multicolumn{3}{|c|}{ Body mass vs depth } & \multicolumn{3}{|c|}{ Abundance vs depth } \\
\hline & $\mathrm{n}$ & $\mathrm{R}$ & $\mathrm{p}$ & $\mathrm{Rt}$ & $\mathrm{Opt}^{\mathrm{a}} / \mathrm{R}^{\mathrm{b}}$ & $\mathrm{p}$ \\
\hline Gaidropsarus biscayensis & 11 & -0.80 & $<0.01$ & unimodal & $529^{a}$ & $<0.001$ \\
\hline Bathypterois mediterraneus & 22 & 0.51 & 0.02 & unimodal & $1677^{\mathrm{a}}$ & $<0.001$ \\
\hline Caelorinchus labiatus & 19 & 0.17 & ns & unimodal & $1451^{\mathrm{a}}$ & $<0.001$ \\
\hline Cataetyx alleni & 7 & 0.92 & $<0.01$ & ns & - & - \\
\hline Centroscymnus coelolepis & 12 & -0.76 & $<0.01$ & linear & $0.71^{b}$ & $<0.001$ \\
\hline Chalinura mediterranea & 15 & 0.77 & $<0.001$ & linear & $0.69^{\mathrm{b}}$ & $<0.001$ \\
\hline Etmopterus spinax & 23 & 0.74 & $<0.001$ & linear & $0.39^{\mathrm{b}}$ & $<0.001$ \\
\hline Galeus melastomus & 31 & 0.66 & $<0.001$ & unimodal & $800^{\mathrm{a}}$ & $<0.001$ \\
\hline Helicolenus dactylopterus & 6 & 0.08 & ns & unimodal & $400^{\mathrm{a}}$ & $<0.001$ \\
\hline Hoplostethus mediterraneus & 15 & 0.35 & n.s. & linear & $0.50^{\mathrm{b}}$ & $<0.01$ \\
\hline Hymenocephalus italicus & 16 & 0.86 & $<0.001$ & unimodal & $633^{\mathrm{a}}$ & $<0.001$ \\
\hline Lepidion lepidion & 19 & 0.74 & $<0.001$ & unimodal & $1425^{\mathrm{a}}$ & $<0.001$ \\
\hline Merluccius merluccius & 7 & 0.93 & $<0.01$ & unimodal & $600^{\mathrm{a}}$ & $<0.001$ \\
\hline Mora moro & 16 & -0.21 & ns & unimodal & $1026^{\mathrm{a}}$ & $<0.001$ \\
\hline Nettastoma melanurum & 20 & -0.26 & ns & unimodal & $1063^{\mathrm{a}}$ & $<0.001$ \\
\hline Nezumia aequalis & 26 & 0.49 & $<0.01$ & unimodal & $944^{\mathrm{a}}$ & $<0.001$ \\
\hline Notacanthus bonapartei & 15 & 0.54 & n.s. & unimodal & $908^{a}$ & $<0.01$ \\
\hline Phycis blennoides & 21 & 0.89 & $<0.001$ & linear & $0.57^{\mathrm{b}}$ & $<0.001$ \\
\hline Polyacanthonotus rissoanus & 11 & 0.63 & 0.04 & linear & $0.56^{\mathrm{b}}$ & $<0.001$ \\
\hline Symphurus ligulatus & 13 & 0.27 & ns & unimodal & $654^{\mathrm{a}}$ & $<0.001$ \\
\hline Symphurus nigrescens & 6 & 0.07 & ns & linear & $0.33^{\mathrm{b}}$ & $<0.001$ \\
\hline
\end{tabular}

The depth distribution of abundance for single species was well-fitted to a unimodal or linear function for all species except for Cataetyx alleni (Table 7), showing different maxima in shallow (Phycis blennoides, Hymenocephalus italicus, Hoplostetus mediterraneus, Gaidropsarus biscayensis, Etmopterus spinax and Symphurus ligulatus), intermediate (Nezumia aequalis, Galeus melastomus, Nettastoma melanurum, Mora moro, Notacanthus bonapartei, and Alepocephalus rostratus) and deep (Lepidion lepidion, Centroscymnus coelolepis, Bathypterois mediterraneus, Chalinura mediterranea and Polyacanthonotus rissoanus) waters (Fig. 6a). In contrast, the linear relationship of $\log _{2}$ body mass of single species with depth indicated that only 13 out of 23 species analysed increased significantly with depth, 2 species revealed a significant

FIG. 6. - Fitted relationship of a) abundance (Gaussian or logistic response curves), and b) body mass (linear regression) related to within-species trend with depth. Only those species of Table 7 with $\mathrm{n}>10$ are represented. Ar, Alepocephalus rostratus; Gb, Gaidropsarus biscayensis; Bm, Bathypterois mediterraneus; Cl, Caelorinchus labiatus; Cc, Centroscymnus coelolepis; $\mathrm{Cm}$, Chalinura mediterranea; Es, Etmopterus spinax; Gm, Galeus melastomus; Hm, Hoplostethus mediterraneus; Hi, Hymenocephalus italicus; Ll, Lepidion lepidion; Mm, Mora moro; Nm, Nettastoma melanurum; Na, Nezumia aequalis; Nb, Notacanthus bonapartei; $\mathrm{Pb}$, Phycis blennoides; $\mathrm{Pr}$, Polyacanthonotus rissoanus; S1, Symphurus ligulatus.
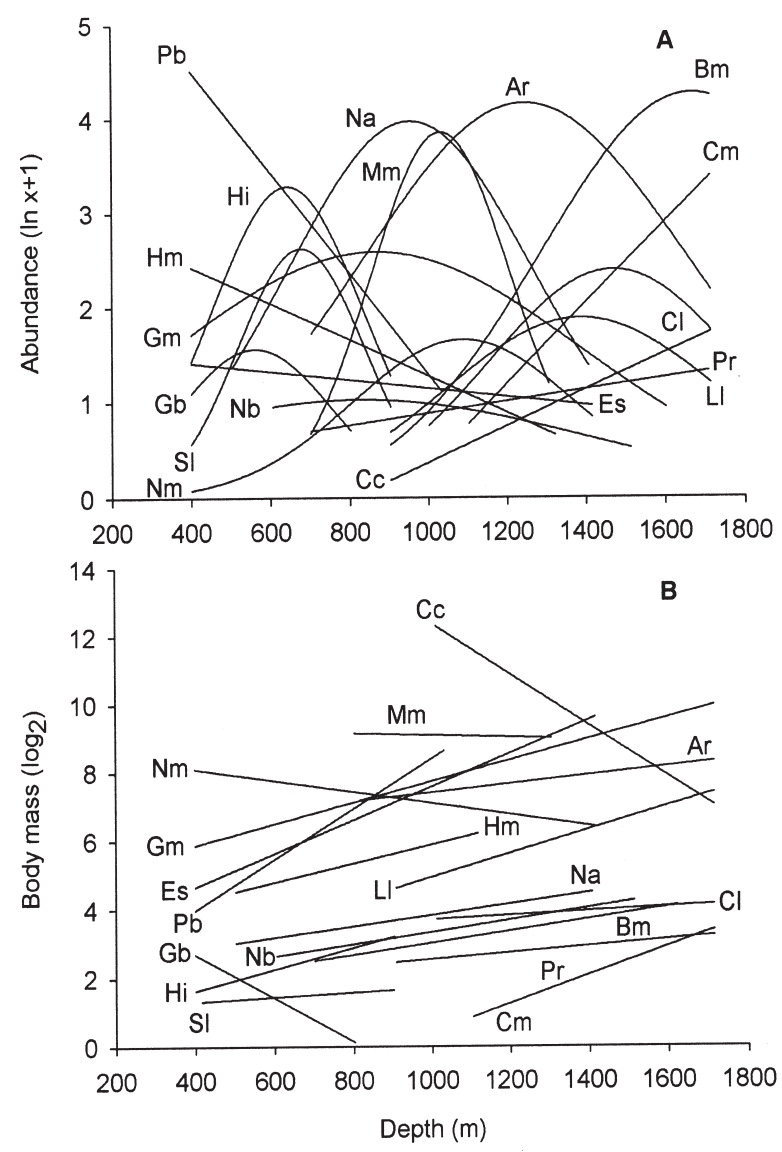
decrease in size, and 8 species did not show any specific trend (Table 7, Fig. 6b).

\section{DISCUSSION}

The existence of a remarkable biomass peak at the middle slope is one of the most relevant characteristics of the deep-sea fish assemblages. This distinctive feature has been noticed by several authors (Marshall and Merrett, 1977; Gordon and Duncan, 1985; Gordon, 1986; Stefanescu et al., 1993; Moranta et al., 1998) and has been attributed to a sharp reduction of trophic resources at increasing depth and to different bathymetric trends in fish size (Macpherson and Duarte, 1991; Stefanescu et al., 1992, 1993; Merrett and Headrich, 1997; Moranta et al., 1998). Our study further confirms the existence of such a biomass peak in the middle slope of the western Mediterranean Sea.

In addition, the results obtained here help to understand the underlying proximate reasons for this biomass peak at intermediate depths. From the four possible alternatives mentioned in the introduction, we ruled out (i) the 'species richness hypothesis', because this parameter decreased along the whole bathymetric range surveyed (Fig. 2a); (ii) the 'abundance hypothesis', because non-significant differences regarding this parameter were found between the three depth-related fish assemblages (Fig. 2b); and (iii) the hypothesis that the assemblage from the middle slope is built up by larger species, because no bathymetric variation in the mean species biomass could be found (Fig. 4). Therefore, the most plausible explanation must rely on the species-specific bathymetric responses of some species, leading to the predominance of larger individuals at intermediate depths (hypothesis 4). For instance, middle and large-sized species such as Nezumia aequalis, Mora moro and Alepocephalus rostratus, three of the most characteristic deep-sea fishes in terms of both abundance and biomass, attain their highest abundance at depths of 800-1400 $\mathrm{m}$. Moreover, it is also at this depth interval that the largest individuals of several large-sized species dominating on the upper and lower slopes (e.g. Phycis blennoides, Galeus melastomus, Etmopterus spinax and Centroscymnus coelolepis) are to be found.

Regarding the species-specific size-depth relationships of deep-sea fishes, there has been some controversy in the last decade about the existence of a general bigger-deeper phenomenon. Macpherson and Duarte (1991) supported the generality of the bigger-deeper phenomenon at the species level, even though the bathymetric range examined by these authors was limited to the first $750 \mathrm{~m}$ of the slope. In contrast, the study by Stefanescu et al. (1992) carried out for the 1000-2250 m depth interval indicated that the bigger-deeper phenomenon was not a well-established tendency in deep-sea fish assemblages. The disagreement in the results obtained by these authors could stem partly from the different bathymetric ranges they surveyed. However, our own results, showing different bathymetric trends in size at the species level (Fig. 6b) when a wide bathymetric range is considered seem to validate the conclusion reached by Stefanescu et al. (1992). Thus, although the bigger-deeper phenomenon is undoubtedly an important feature of many of the species analysed so far (e.g. Haedrich and Polloni, 1976; Wenner and Musick, 1977; Gordon and Duncan, 1985; Snelgrove and Haedrich, 1985; Macpherson and Duarte, 1991; Stefanescu et al., 1992), it cannot be considered as a general rule for the demersal deep-sea fishes (Gordon, 1979; Crabtree et al., 1985; Stefanescu et al., 1992). Although the same debate has focused on other faunal groups such as nematodes, echinoderms, ophiuroids and decapods, there is now compelling evidence of the lack of any general trend (Rex and Etter, 1998; and references cited therein).

Stefanescu et al. (1992) also postulated the existence of a smaller-deeper trend in the Mediterranean deep sea for the whole demersal fish fauna (the so called 'within-fauna pattern'). This pattern resulted from the replacement of the dominant medium to large-sized species on the middle slope by small ones on the lower slope, probably as a consequence of the lower trophic availability at increasing depths. In our study, in which the entire middle slope and most of the upper and lower slopes were sampled, the within-fauna pattern for the mean body size consisted of two opposite trends: (i) an increase in size with depth in the first $1000 \mathrm{~m}$; and (ii) a decrease below this depth (Fig. 5a). The former was also paralleled by an increase in the mean maximum body mass. In contrast, even though the mean body size diminished below $1000 \mathrm{~m}$, small and large-sized specimens still coexisted at increasing depths (Fig. $5 b)$. Our results thus indicate that the smaller-deeper trend for the whole fauna is not a well-established phenomenon, even in the case in which only the middle and lower slopes were considered. 
Interestingly, Cartes et al. (2001) reported, for the same study area, and between 800 and $1300 \mathrm{~m}$ depth, the existence of a biomass peak in the suprabenthos, the principal component of the Benthic Boundary Layer (Cartes, 1998a). As shown in several studies, the suprabenthos is a fundamental part of the diet of deep-water fishes (Macpherson, 1981; Carrassón, 1994). Thus, the minor availability of trophic resources above and below this depth interval may ultimately determine the lower biomass characterising the upper and lower slope fish assemblages (see also Stefanescu et al., 1993). On the other hand, the biomass of another major group of predators, namely the decapod crustaceans, which also prey on the suprabenthos (Cartes, 1994; 1998b) peaks between 400-700 m (Maynou and Cartes, 2000), and Cartes et al. (2001) have suggested that this may originate a phenomenon of competitive exclusion in favour of the latter group of megafaunal predators at this depth interval due to the exploitation of similar resources.

The general low levels of biomass of fish assemblages occurring on the lower slope can be explained in terms of the scarcity of trophic resources at the greatest depths. In addition, this factor may have imposed a strong selection pressure for a diversification in the trophic strategies of the fish species inhabiting the lower slope, which may explain the already mentioned coexistence of small and large-sized species (e.g. Bathypterois mediterraneus, Lepidion lepidion, Alepocepahlus rostratus and Centroscymnus coelolepis; Carrassón et al., 1992; Carrassón et al., 1997, Carrassón and Matallanas, 1998).

The existence of a major proportion of larger specimens of larger species on the middle slope is confirmed when the normalised biomass spectra (NBS) are analysed (Fig. 3). Thus, the NBS found in this assemblage is composed of a large fraction of individuals of large size classes. The fraction of the biomass along large size classes is also represented in the lower assemblage, but in a lesser percentage. In contrast, the absence of larger specimens is the main feature of the upper slope. The Balearic Islands are characterised by an important trawl fishing activity all around the upper slope (Merella et al., 1998; Carbonell et al., 1999; García-Rodríguez and Esteban, 1999; Moranta et al., 2000). The principal effects of fishing on the size and species composition of multi-species communities are well known (Jennings et al., 2001). Thus, as fishing mortality rises, the mean size of individuals in the community falls, and species with larger body sizes form a smaller proportion of community biomass (Jennings and Kaiser, 1998; Gislason and Sinclair, 2000). These effects seem to be apparent in our study area, because, as shown above, the main difference between the upper (400-800 m depth) and the other two assemblages (800-1400 and 1400-1800 m depth) analysed is the small proportion of large specimens in the community at shallower depths. Therefore, under natural conditions, higher biomass values, with larger species and specimens, may occur at this depth interval, so the biomass peak would be displaced towards an upper bathymetric level.

\section{ACKNOWLEDGEMENTS}

This paper is a result of the European Project "Developing deep-water fisheries: data for their assessment and for understanding their interaction with an impact on a fragile environment" (EU FAIR Project CT 95-0655; European Commission DG XIV Fisheries). The authors thank all the participants of the sampling cruises Quimera-I and Quimera-II for their help.

\section{REFERENCES}

Carbonell, A., M. Carbonell, M. Demestre, A. Grau and S. Monserrat. - 1999. The red shrimp Aristeus antennatus (Rissao, 1816) fishery and biology in the Balearic Islands, Western Mediterranean. Fish. Res., 44: 1-13

Carney, R.S., R.L. Haedrich and G.T. Rowe. - 1983. Zonation of the fauna in the deep-sea. In: G.T. Rowe (ed.), Deep-sea biology, the sea (8), pp. 371-398. Wiley Interscience, New York.

Carrassón, M. - 1994. Relaciones tróficas en las comunidades ícticas bentónicas (de 1000 a 2200 m) en el mar Catalán. Ph.D. thesis, Universidad Autónoma de Barcelona.

Carrassón, M., C. Stefanescu and J.E. Cartes. - 1992. Diets and bathymetric distributions of two bathyal sharks of the Catalan deep sea (western Mediterranean). Mar. Ecol. Prog. Ser., 82: 21-30.

Carrassón, M. and J. Matallanas. - 1998. Feeding habits of Alepocephalus rostratus (Pisces: Alepocephalidae) in the western Mediterranean Sea. J. Mar. Biol. Assoc. UK, 78: 1295-1306.

Carrassón, M., J. Matallanas and M. Casadevall. - 1997. Feeding strategies of deep-water morids on the western Mediterranean slope. Deep-Sea Res., 44: 1685-1699.

Cartes, J.E. - 1994. Influence of depth and seasonality in the diet of the deep-water shrimp Aristeus antennatus along the slope (between 400-2300 m). Mar. Biol., 120: 639-648.

Cartes, J.E. - 1998a. Dynamics of the bathyal Benthic Boundary Layer in the northwestern Mediterranean: depth and temporal variations in macrofaunal-magafaunal communities and their possible connections within deep-sea trophic webs. Prog. Oceanogr., 41: 111-139.

Cartes, J.E. - 1998b. Feeding strategies and partition of food resources in deep-water decapod crustaceans in relation to depth (between 400-2300 m). J. Mar. Biol. Assoc. UK, 78: 509-524.

Cartes, J.E. and F. Sardà. - 1993. Zonation of deep-sea decapod fauna in the Catalan Sea (western Mediterranean). Mar. Ecol. Prog. Ser., 94: 24-34.

Cartes, J.E., F. Maynou, B. Morales-Nin, E. Massutí and J. Moranta. 
- 2001. Trophic structure of a bathyal benthopelagic boundary layer community south of the Balearic Islands (souhtwestern Mediterranean). Mar. Ecol. Prog. Ser., 215: 23-35.

Clarke, K.R. and R.H. Green. - 1988. Statistical design and analysis for a 'biological effects' study. Mar. Ecol. Prog. Ser., 46: 213-226.

Cohen, D.M. and D.L. Pawson. - 1977. Observations from the DSRV ALVIN on populations of benthic fishes and selected larger invertebrates in a near Deep Water Dumpsite-106. N.O.A.A. Dump. Eval. Rep., 77-1(2): 423-458.

Crabtree, R.E., K.J. Sulak and J.A. Musik. - 1985. Biology and distribution of species of Polyacanthonotus (Pisces: Notacanthiformes) in the western North Atlantic. Bull. Mar. Sci., 36: 235-248.

García-Rodríguez, M. and A. Esteban. - 1999. On the biology and fishery of Aristeus antennatus (Risso, 1816), (Decapoda, Dendrobranchiata) in the Ibiza Channel (Balearic Islands, Spain). Sci. Mar., 63(1): 27-37.

Gislason, H. and M.M. Sinclair. - 2000. Ecosystems effects of fishing. ICES J. Mar. Sci., 57: 465-791.

Gordon, J.D.M. - 1979. Lifestyle and phenology in deep sea anacanthine teleosts. Symp. Zool. Soc. Lond., 44: 327-359.

Gordon, J.D.M. - 1986. The fish populations of the Rockall Trough. Proc. Roy. Soc. Edimb., 88(B): 191-204.

Gordon, J.D.M. and J.A.R. Duncan. - 1985. The ecology of the deepsea benthic and benthopelagic fish on the slopes of the Rockall Trough, Northeastern Atlantic. Prog. Oceanogr., 15: 37-69.

Gordon, J.D.M. and J.A.R. Duncan. - 1987. Deep-sea bottom-living fishes at two repeat stations at 2200 and $2900 \mathrm{~m}$ in the Rockal Trough, northeastern Atlantic Ocean. Mar. Biol., 96: 309-325.

Gordon, J.D.M., N.R. Merrett and R.L. Haedrich. - 1995. Environmental and biological aspects of slope dwelling fishes of the north Atlantic. In: AG Hopper (ed.), Deep water fisheries of the North Atlantic oceanic slope. Kluwer Academic Publisher, Netherlands.

Grassle, J.F., H.L. Sanders, R.R. Hessler, G.T. Rowe and T. McLellan. - 1975. Pattern and zonation - a study of the bathyal megafauna using the research submersible Alvin. Deep-Sea Res., 22: 457-481.

Haedrich, R.L. and G. Krefft. - 1978. Distribution of bottom fishes in the Denmark Strait and Irminger Sea. Deep-Sea Res., 25: 705-720.

Haedrich, R.L. and N.R. Merrett. - 1992. Production biomass ratios, size frequencies, and biomass spectra in deep-sea demersal fishes. In: G.T. Rowe and V. Pariente (eds.), Deep-sea food chains and the global carbon cycle, pp. 157-182. Kluwer Academic Publishers. Netherlands.

Haedrich, R.L., G.T. Rowe and P. T. Polloni. - 1980. The megabenthic fauna in the deep-sea south of New England, USA. Mar. Biol., 57: 165-179.

Haedrich, R.L. and G.T. Rowe. - 1977. Megafaunal biomass in the deep-sea. Nature, Lond., 269: 141-142.

Haedrich, R.L. and P.T. Polloni. - 1976. A contribution to the life history of a small rattail fish, Coryphaenoides carapinus. Bull. South. Calif. Acad. Sci., 75: 203-211.

Hecker, B. - 1990. Variation in megafaunal assemblages on the continental margin south of New England. Deep-Sea Res., 37: 35-57.

Hope, A.C.A. - 1968. A simplified Monte Carlo significance test procedure. J. R. Statistic. Soc. Ser. B, 30: 582-598.

Jennings, S. and M.J. Kaiser. - 1998. The effects of fishing on marine ecosystems. Adv. Mar. Biol., 34: 201-352.

Jennings, S., M.J. Kaiser and J.D. Reynolds. - 2001. Marine fisheries ecology. Blackwell Science Ltd, London.

Koslow, J.A. - 1993. Community structure in North Atlantic deepsea fishes. Prog. Oceanogr., 31: 321-338

Legendre, P. and L. Legendre. - 1998. Numerical ecology. Elsevier Science B.V., Amsterdam.

Macpherson, E. - 1981. Resource partitioning in a Mediterranean demersal fish community. Mar. Ecol. Prog. Ser., 4: 183-193.

Macpherson, E. and A. Gordoa. - 1996. Biomass spectra in benthic fish assemblages in the Benguela System. Mar. Ecol. Prog. Ser. 138: 27-32.

Macpherson, E. and C.M. Duarte. - 1991. Bathymetric trends in demersal fish size: is there a general relaionship? Mar. Ecol. Prog. Ser., 71: 103-112.

Marshall, N.B. and N.R. Merrett. - 1977. The existence of benthopelagic fauna in the deep-sea. Deep-Sea Res., 24(Suppl.): 483-497.
Mauchline, J. and J.D.M. Gordon. - 1984. Diets and bathymetric distribution of the macrourid fish of the Rockall Trough, north eastern Atlantic Ocean. Mar. Biol., 81: 107-121.

Maynou, F. and J.E. Cartes. - 2000. Community structure of bathyal decapod crustaceans off south-west Balearic Islands (western Mediterranean): seasonality and regional patterns in zonation. J. Mar. Biol. Ass. U.K., 80: 789-798.

Merella, P., A. Quetglas, F. Alemany and A. Carbonell. - 1997. Length-weight relationship of fishes and cephalopods from the Balearic Islands (western Mediterranean). Naga, ICLARM Ouart, 20(3-4): 66-68.

Merella, P., F. Alemany, A. Carbonell and A. Quetglas. - 1998. Fisheries and biology of Norway lobster Nephrops norvegicus (Decapoda: Nephropidae) in Mallorca (western Mediterranean). J. Nat. Hist., 32: 1631-1640.

Merrett, N.R. and R.L. Haedrich. - 1997. Deep-sea demersal fish and fisheries. Chapman and Hall, London.

Merrett, N.R. and P.A. Domanski. - 1985. Observations on the ecology of deep-sea bottom living fishes collected off northwest Africa: II. The Moroccan slope $\left(27^{\circ}-34^{\circ} \mathrm{N}\right)$, with special reference to Synaphobranchus kaupi. Biol. Oceanogr., 3: 349-399.

Merrett, N.R. and N.B. Marshall. - 1981. Observations on the ecology of deep-sea bottom living fishes collected off northwest Africa $\left(08^{\circ}-27^{\circ} \mathrm{N}\right)$. Prog. Oceanogr., 9: 185-244.

Merrett, N.R., J.D.M. Gordon, M. Stehmann and R.L. Haedrich. 1991. Deep demersal fish assemblages structure in the Porcupine Seabight (eastern North Atlantic): slope sampling by three different trawls compared. J. Mar. Biol. Ass. UK, 71: 329-358.

Middleton, R.W. and J. Musick. - 1986. The abundance and distribution of the family Macrouridae (Pisces: Gadiformes). Fish Bull., U.S., 84: 35-62.

Moranta, J., C. Stefanescu, E. Massutí, B. Morales-Nin and D. Lloris - 1998. Fish community structure and depth-related trends on the continental slope of the Balearic Islands (Algerian basin, western Mediterranean). Mar. Ecol. Prog. Ser., 171: 247-259.

Moranta, J., E. Massutí and B. Morales-Nin. - 2000. Fish catch composition of the deep-sea decapod crustacean fisheries in the Balearic Islands (western Mediterranean). Fish. Res., 45: 253-264.

Morey, G., J. Moranta, E. Massutí, A. Grau, M. Linde, F. Riera and B. Morales-Nin - 2003. Weight-length relationship of littoral to lower slope fishes from the western Mediterranean. Fish. Res., 62: 89-96.

Pearcy, W.G., D.L. Stein and R.S. Carney. - 1982. The deep-sea benthic fish fauna of the northeastern Pacific Ocean on Cascadian and Tufts Abyssal plains adjoining continental slopes. Biol. Oceanogr., 1: 375-428.

Peters, R.H. - 1983. The ecological implications of body size. Cambridge University Press, Cambridge.

Polloni, P., R.L. Haedrich, G. Rowe and C.H. Clifford. - 1979. The size-depth relationship in deep ocean animals. Int. Revue. ges. Hydrobiol., 64: 39-46.

Rex, M.A. and R.J. Etter.- 1998. Bathymetric patterns of body size: implications for deep-sea biodiversity. Deep-Sea Res., 45: 103-127.

Sardà, F., J.E. Cartes, J.B. Company and A. Albiol. - 1998. A modified commercial trawl used to sample deep-sea megabenthos. Fish. Sci., 64: 492-493.

Snelgrove, P.V.R. and R.L. Haedrich. - 1985. Structure of the deep demersal fish off Newfoundland. Mar. Ecol. Progr. Ser., 27: 99-107.

Stefanescu, C., B. Morales-Nin and E. Massutí. - 1994. Fish assemblages in the Catalan Sea (western Mediterranean): influence of a submarine canyon. J. Mar. Biol. Ass. UK., 74: 499-512.

Stefanescu, C., D. Lloris and J. Rucabado. - 1993. Deep-sea fish assemblages in the Catalan Sea (western Mediterranean) below a depth of 1000 m. Deep-Sea Res., 40: 695-707.

Stefanescu, C., J. Rucabado and D. Lloris. - 1992. Depth-size trends in western Mediterranean demersal deep-sea fishes. Mar. Ecol. Prog. Ser., 81: 205-213.

Sulak, K.J. - 1982. A comparative taxonomic and ecological analysis of temperate and tropical demersal deep-sea fish faunas in the Western North Atlantic. Ph.D. thesis, University of Miami.

ter Braak, C.J.F and P. Smilauer. - 2002. CANOCO Reference manual and CanoDraw for Windows user's guide: Software for Canonical Community ordination (version 4.5). Microcomputer Power, Ithaca, NY, USA

Wenner, C.A. and J.A. Musick. - 1977. Biology of the morid fish Antimora rostrata in the western North Atlantic. J. Fish. Res. B. Can., 34: 2362-2368. 